\title{
A REPORT CARD ON THE IMPEACHMENT: JUDGING THE INSTITUTIONS THAT JUDGED PRESIDENT CLINTON
}

\author{
SUSAN LOW BLOCH*
}

I

\section{INTRODUCTION}

Now that we have lived through one of the most unusual events in American history-the impeachment and trial of the President of the United States-it is appropriate, indeed essential, that we assess how the process worked and learn what we can from it. Specifically, I want to address two questions: First, how well did the impeachment process work? In good academic fashion, I will grade each of the governmental institutions involvedgiving them, if you will, a report card. Second, what did we learn from the experience to guide us if, in the future, we face the impeachment of a President?

Let me start by saying that President Clinton's misbehavior was inexcusable. Had he been more disciplined, the nation would have been spared a year of agony. But his "inappropriate" ${ }^{1}$ relationship with Monica Lewinsky was neither criminal nor impeachable. ${ }^{2}$ Had he been more forthright when confronted in January 1998, we probably also would have been spared the year of torture. However, the $\$ 64,000$ question is whether his efforts to spare himself, his family, and Monica Lewinsky the embarrassment of disclosure were impeachable

Copyright (C) 2000 by Susan Low Bloch

This article is also available at http://www.law.duke.edu/journals/63LCPBloch.

* Professor of Law, Georgetown University Law Center.

I greatly appreciate the useful suggestions I received from my colleagues Vicki Jackson and Neal Katyal, as well as the input of those attending the conference at Duke University School of Law in September 1999. I also want to thank my research assistants, Steve Glass, Jen Gruda, and Joshua Hess, for their hard work on this article.

1. In his grand jury testimony, President Clinton said that he and Lewinsky had "inappropriate intimate contact." H.R. DoC. No. 105-311, at 461 (1998).

2. No one seriously contended that the affair was an impeachable offense. Indeed, one of the most commonly repeated phrases during the impeachment debate was "This is not about sex." Representative Henry Hyde's comments were typical: "The question before this House is rather simple. It is not a question of sex. Sexual misconduct and adultery are private acts and are none of Congress' business." 144 CONG. REC. H11,776 (1998). Similar sentiments were expressed in the Senate: "We must start by saying that this trial has never been about the President's private sex acts, as tawdry as they may have been." 145 CONG. REC. S1501 (1999) (statement of Sen. Peter Domenici). 
offenses.

Before beginning the evaluation, I would like to disclose my personal connection with the saga. I first became involved when Paula Jones sued the President in 1994. I argued, in an op-ed, that a private damage action against a sitting President must wait until the President is out of office, unless the plaintiff can show irreparable harm from such a delay. ${ }^{3}$ After the Supreme Court ultimately rejected that argument ${ }^{4}$ and Independent Counsel Ken Starr ${ }^{5}$ sent his referral to the House of Representatives, I urged members of the House not to impeach. ${ }^{6}$ I was also one of the law professors who drafted and circulated the letter arguing that the President's actions did not warrant impeachment. Furthermore, I was one of the nineteen constitutional scholars who testified before the House Judiciary Committee on impeachment. ${ }^{8}$ After the House voted to impeach the President, I counseled members of the Senate on their role in the President's trial. In short, I am not unbiased but believe I can be fair in evaluating the performance of the various institutions involved, giving a grade to each of them.

3. See Susan Low Bloch, Constitutional Balancing Act, WASH. Post, June 11, 1994, at A20.

4. See Clinton v. Jones, 520 U.S. 681 (1997).

5. Judge Starr was appointed independent counsel in August 1994, to take over the investigation of Whitewater, replacing Robert Fiske, who had been appointed by Attorney General Reno during a period in which the independent counsel statute had lapsed. See Stephen Labaton, The Whitewater Inquiry: The Decision; Judges Appoint New Prosecutor for Whitewater, N.Y. TIMES, Aug. 6, 1994, at A1. Starr's jurisdiction was subsequently expanded several times, and ultimately included the investigation of the firings in the White House Travel Office, the suicide of Deputy White House Counsel Vince Foster, the alleged misuse of FBI files, and the alleged obstruction of justice in the Jones case. See The Impeachment and Trial of President Clinton: The OfFicial Transcripts, FROM the House Judiciary COMmitTeE HeARINGs to THE SEnATE Trial xiv-xv (Merrill McLoughlin ed., 1999).

6. See Eric Schmitt, Democrats Fill the Breach with a Session on Impeachment History, N.Y. TimES, Oct. 16, 1998, at A18.

7. See 144 CONG. REC. H11,892 (1998). The letter received more than 443 signatures. Our letter, plus a similar one by constitutional historians, apparently influenced at least some members of the House and the Senate. In the House, Representative Maxine Waters stated, "[T]he 19 experts who appeared before the Subcommittee on the Constitution, over 400 historians, 400 legal scholars, 10 out of 12 of the Nation's most respected legal minds, and the American people agree that Mr. Starr's allegations do not reach the level of high crimes and misdemeanors." HOUSE COMM. ON THE JUDiCIARY, 105TH CONG., 2D SESS., IMPEACHMENT INQUIRY: William JEFFERSON CLINTON, PRESIDENT OF THE UNITED STATES: CONSIDERATION OF THE ARTIClES OF IMPEACHMENT 102 (Comm. Print 1998) [hereinafter IMPEACHMENT InQUIRY]. In the Senate, Senator Ted Kennedy observed:

In addition to Professor Schlesinger, over 430 law professors and over 400 historians and constitutional scholars have stated emphatically that the allegations against President Clinton do not meet the standard set by the Constitution for impeachment. The scholarly support for the argument that the charges against President Clinton do not rise to the level of impeachable offenses - even if they are true-is overwhelming, and it cannot be ignored.

145 CONG. REC. S1567 (1999).

8. See Background and History of Impeachment: Hearing Before the Subcomm. on the Const. of the House Comm. on the Judiciary, 105th Cong. Rec. 230 (1998) [hereinafter Background and History of Impeachment] (statement of Susan Low Bloch)]. 


\section{THE INDEPENDENT COUNSEL STATUTE}

Any critique of the impeachment process should begin with the independent counsel statute. The statute, at least as it has been constituted to date, gets an "F," and we are fortunate that Congress allowed the law to expire last June."

To say that we are well rid of the statute is not to say that Starr misused it. Indeed, it is important to note that he seems to have been vindicated by the court for the wrongdoings of which he was accused. ${ }^{10}$ In fact, as Professor Gerhardt points out, one of the problems faced by independent counsels is their somewhat unique vulnerability to criticism from their targets. ${ }^{11}$ Our recent experiences under the statute have shown the wisdom of those such as Justice Scalia who questioned its constitutionality from its inception. ${ }^{12}$ The statute's name emphasized the need for independence, but that independence came at a significant price: the loss of accountability. In effect, independent counsels were not accountable to anyone. They had unlimited time, an unlimited budget, and a singular focus, or target. Judgment was not built into the statute. While the Attorney General could theoretically dismiss an independent counsel "for cause," 13 in reality, dismissal was politically impossible. In fact, no independent counsel was ever fired by the Attorney General nor had his investigation terminated by the Special Division. ${ }^{14}$ This tension between accountability and independence was not simply a design defect; in constructing such a statute, there is an unavoidable trade-off between independence and accountability. Both are valuable attributes, but given the inevitability of a trade-off, our recent experiences demonstrate that accountability is more

9. I had urged Congress to allow it to expire. See Susan Low Bloch, Cleaning Up the Legal Debris Left in the Wake of Whitewater, 43 ST. LOUIS U. L.J. 779, 783 (1999). I must confess, however, that I came to this view only after some of the recent excesses. I had been an early supporter of the statute. See Susan Low Bloch, The Early Role of the Attorney General in our Constitutional Scheme: In the Beginning There was Pragmatism, 1989 DUKE L.J. 561, 647 (1989) ("Congress had confronted a difficult problem and conscientiously tried to forge a narrow solution that minimized the threat to separation of powers.").

10. See In re Sealed Case No. 99-3091 (Office of Independent Counsel Contempt Proceeding), 192 F.3d 995 (D.C. Cir. 1999).

11. See Michael J. Gerhardt, The Historical and Constitutional Significance of the Impeachment and Trial of President William Jefferson Clinton, 28 HOFSTRA L. REV. 349, 352 (1999).

12. See Morrison v. Olson, 487 U.S. 654, 729-30 (1988) (Scalia, J., dissenting) ("An independent counsel is selected, and the scope of his or her authority prescribed, by a panel of judges. What if they are politically partisan, as judges have been known to be, and select a prosecutor antagonistic to the administration, or even to the particular individual who has been selected for this special treatment? There is no remedy for that, not even a political one.").

13. 28 U.S.C. $§ 596(a)(1)(1994)$. "An independent counsel appointed under this chapter may be removed from office, other than by impeachment and conviction, only by the personal action of the Attorney General and only for good cause, physical or mental disability." Id. The Special Division that appoints the independent counsel "may terminate an office of independent counsel at any time, on the ground that the investigation of all matters within the prosecutorial jurisdiction of such independent counsel... have been completed or so substantially completed that it would be appropriate for the Department of Justice to complete such investigations and prosecutions." Id. § 596(b). (1998).

14. See Donald C. Smaltz, The Independent Counsel: A View From Inside, 86 GEO. L.J. 2307, 2326 
important than independence, and that independence can be achieved without a special statute.

The Independent Counsel statute was first enacted in the wake of Watergate's Saturday night massacre when President Nixon ordered that thenSpecial Prosecutor Archibald Cox be fired. ${ }^{15}$ Congress sought to make it more difficult for future Presidents to replicate Nixon's actions,${ }^{16}$ but we tend to forget that President Nixon was held accountable for firing Cox. The public was so outraged by Cox's firing that President Nixon was politically compelled to appoint a new special prosecutor, Leon Jaworski. ${ }^{17}$ Thus, Watergate was successfully investigated-and successfully resolved-without an independent counsel statute. Moreover, after the most recent statute expired in June 1999, Attorney General Janet Reno appointed former Senator John Danforth to investigate the Waco incident, making it clear that we do not need a special independent counsel statute to get independent investigations. ${ }^{18}$ In hindsight, with the wisdom imparted by some of the excessive prosecutions in the last two decades, I was glad to see the statute expire..$^{19}$

15. See StAnley I. Kutler, The WARs of Watergate: The LAST CRisis OF Richard NiXoN 406-26 (1990). "The draconian dismissal of Archibald Cox assured the appointment of a new Special Prosecutor, one with even more ironclad guarantees of independence than Cox had had." Id. at 426.

16. The statute was first enacted in 1978, with a five-year sunset provision. Ethics in Government Act, Pub. L. No. 95-521, 92 Stat. 1824 (codified at 28 U.S.C. $\$ \S 591-598$ (1982)). It was thereafter enacted several more times, each time with some modifications and always with a five-year sunset provision. In 1982, it was extended under the Ethics in Government Act Amendments of 1982, Pub. L. 97-409, 49 Stat. 1293. In 1987, it was extended again under the Independent Counsel Reauthorization Act of 1987, Pub. L. No. 100-191, 101 Stat. 1293. The last re-enactment was in 1994 in the Independent Counsel Reauthorization Act of 1994, Pub. L. No. 103-270, 108 Stat. 732 (codified as amended at 28 U.S.C. \$§ 590-599) (1994)).

17. See KUTLER, supra note 15, at 406-26.

18. The appointment of former Senator John Danforth to investigate the Waco incident, after the expiration of the statute, shows that independent investigations do not have to be directed or controlled by a special statute. See David A. Vise \& Lorraine Adams, Aggressive Waco Probe is Promised, WASH. POST, Sept. 10, 1999, at A1. The history of the use of independent counsels hired without the existence of a special statute is recounted in Smaltz, supra note 14, at 2311-21.

19. The Act had generated considerable criticism. See, e.g., Colloquy, The Independent Counsel Process: Is It Broken and How Should It Be Fixed?, 54 WASH. \& LEE L. REV. 1515 (1997); Symposium, The Future of the Independent Counsel Act, 49 MERCER L. REV. 427 (1998); Symposium, The Independent Counsel Act: From Watergate to Whitewater and Beyond, 86 GEO. L.J. 2011 (1998); AM. ENTER. Inst. \& THE BROOKINGS InST., THE PROJECT ON THE INDEP. COUNSEL STATUTE, REPORT \& RECOMMENDATIONS (1999) (visited Apr. 4, 2000) <http://www.brooke.edu/gs/ic/report/rptfull.htm>.

Many commentators, including some former independent counsels, urged Congress to refuse to reenact the statute. See, e.g., Joseph E. diGenova, The Independent Counsel Act: A Good Time to End a Bad Idea, 86 GEO. L.J. 2299, 2301 (1998); Cass R. Sunstein, Bad Incentives and Bad Institutions, 86 GEO. L.J. 2267, 2274-75 (1998); Dan Morgan, Restraint Urged on Changing Counsel Law: Congress Must "Cool Off", Ex-Sen. Baker Tells Panel, WASH. Post, Feb., 25, 1999, at A4. Kenneth Starr attacked the statute, calling it "structurally unsound... constitutionally dubious... [and] disingenuous." Mike Dorning, Starr Testimony Splits Panel, Counsel Law Debate Revives Acrimony Over Clinton Trial, Sun SENTINEL, Apr. 15, 1999, at 6A. Most of those former independent counsels who believed such a law is desirable agreed that any re-enactment should be substantially revised. See Todd S. Purdum, Former Special Counsels See Need to Alter Law that Created Them, N.Y. TIMES, Aug. 11, 1998, at A1.

The loss of the statute clearly has costs. When an independent counsel operates well and decides not to indict, vindication is all the more valuable. See Don Van Natta, Jr., Babbitt Case Won't Yield Indictments, Lawyers Say, N.Y. TIMES, Aug. 12, 1999, at A14 (discussing Independent Counsel Carol 
The worst feature of the independent counsel statute and the one that caused the most mischief during the Clinton impeachment was section 595(c), which required the independent counsel to report to the House of Representatives if he finds "any substantial and credible information ... that may constitute grounds for an impeachment." ${ }^{20}$ This delegation of congressional authority to the independent counsel was constitutionally suspect. ${ }^{21}$ The provision delegated too much of the House's constitutional responsibility to decide whether to initiate an impeachment inquiry to an unelected and unaccountable individual. ${ }^{22}$ When Ken Starr publicly delivered his thirty-six boxes of "evidence," it was practically impossible for the House to decide not to initiate an impeachment inquiry. That distorts the impeachment process, which is carefully designed to be a dispute between the two elected branches-Congress and the President. It is no accident the Constitution vests "the sole power" to impeach in the branch most accountable to the people-the House of Representatives whose members face the electorate every two years. ${ }^{23}$ The intervention of an unaccountable intermediary transforms and grossly distorts the process. ${ }^{24}$ A decision to initiate an impeachment inquiry should be a

Elder Bruce's decision not to indict Interior Secretary Bruce Babbitt). However, the absence of an independent counsel statute does not mean that there is no mechanism for investigating wrongdoing by high executive officials. Anticipating that the statute would not be renewed, Attorney General Reno proposed regulations to deal with such investigations. See Editorial, Special Counsel Rules, WASH. Post, July 6, 1999, at A14; see also Roberto Suro, As Special Counsel Law Expires, Power Will Shift to Reno, WAsH. Post, June 30, 1999, at A6. Under the regulations, adopted on July 9, 1999, the Attorney General has the power to appoint and remove special counsels to investigate the President, Vice President, Cabinet officials, and any other person with whom there might be a conflict of interest between the DOJ and the subject of the investigation. See 28 C.F.R. $\$ 600$ (1999). The Attorney General will also have substantial power over indictments, appeals, and other major investigative steps. See id. § 600.7(b). "[T]he Attorney General may request that the Special Counsel provide an explanation for any investigative or prosecutorial step, and may after review conclude that the action is so inappropriate or unwarranted ... that it should not be pursued." Id.

20. 28 U.S.C. $\$ 595(\mathrm{c})$ (1994). The Starr Report is the Independent Counsel's Referral to the House of Representatives, as required by section 595(c). See Referral from Independent Counsel Kenneth W. Starr, H.R. Doc. No. 105-310, (Sept. 11, 1998).

21. See Bloch, Cleaning Up the Legal Debris, supra note 9, at 783.

22. For a more detailed discussion of this idea, see Ken Gormley, Impeachment and the Independent Counsel: A Dysfunctional Union, 51 STAN. L. REV. 309 (1999); Julie R. O'Sullivan, The Interaction Between Impeachment and the Independent Counsel Statute, 86 GEO. L.J. 2193 (1998); Julie R. O'Sullivan, The Independent Counsel Statute: Bad Law, Bad Policy, 33 AM. CRIM. L. REV. 463 (1996).

23. U.S. ConsT. art. I, $\S 2$, cl. 5 (emphasis added).

24. This distortion is especially serious if the independent counsel continues to play a significant prosecutorial role in the congressional proceedings. Independent Counsel Starr's report may itself have been too adversarial. See Gerald Goldman, Report by Starr Oversteps Statutory Authority, NAT'L L.J., Oct. 19, 1998, at A28. Starr's subsequent testimony before the House was even more adversarial and led his ethics adviser, Professor Sam Dash, to opine that Starr had gone too far and to resign. See Independent Counsel Kenneth Starr's Prepared Testimony for Delivery Before the House Judiciary Committee, 1998 WL 801023 (F.D.C.H. Nov. 19, 1998); see also Samuel Dash, Letter to the Editor, Sam Dash Replies, WASH. Post, Nov. 24, 1998, at A18 ("Mr. Starr's willingness to play [the role of impeachment prosecutor] violates not only the separation of powers principles, but the Constitution's demand that the sole power of impeachment is in the House."); Alison Mitchell, Rancorous House Panel Hears Starr's Case for Impeachment, N.Y. TIMES, Nov. 20, 1998, at A1; Letter of Resignation from Samuel Dash and Kenneth Starr's Letter in Response, N.Y. TIMES, Nov. 21, 1998, at A10. Starr defended his actions: 
more difficult and more carefully thought-out process than what occurred in 1998. ${ }^{25}$ For these reasons, I am confident the independent counsel statute deserves an " $F$," and we are well rid of it. ${ }^{26}$

III

\section{THE HOUSE OF REPRESENTATIVES}

The House of Representatives also earns a failing grade on the impeachment report card. Once Independent Counsel Starr dramatically delivered his evidence to the steps of the House, deciding to initiate an impeachment inquiry was virtually a forgone conclusion. Therefore, the House should not be faulted for that decision. However, thereafter, virtually every decision the House made was poorly reasoned, partisan, and wrong. The nation witnessed a series of missed opportunities and bad judgments.

The House should have started the inquiry by exploring the nature of an impeachable offense and whether the alleged actions of the President amounted to such an offense. ${ }^{27}$ As only the third impeachment inquiry of a President in our history, the House had a valuable opportunity to debate and decide what constitutes an impeachable offense by a President. Unfortunately, the House never seriously engaged in such an inquiry. Instead, the Representatives voted immediately to put the Starr Report online without even reading it-even

$[\mathrm{M}] \mathrm{y}$ view is I had an invitation to explain ... what was in the referral .... The other thing I would say in this respect is that we really are ... in uncharted waters. This is the first time, unhappily for the country, that under the independent counsel law a referral has been made to Congress.

Richard A. Serrano \& Marc Lacey, Starr Testimony Spurs Ethics Advisor to Quit, L.A. TIMES, Nov. 21, 1998, at A21 (quoting Independent Counsel Kenneth Starr).

Starr's continued involvement in the impeachment process once it was in the Senate, especially his efforts to assist the House Managers in their efforts to meet informally with Monica Lewinsky to prepare for the Senate trial, raised serious questions about his claimed impartiality and neutrality. See Bob Hohler, Lewinsky Summons Ignites a Firestorm, Boston GlobE, Jan. 24, 1999, at A1; Kurt Royce \& Shirley E. Perlman, The Impeachment Trail: Scholars Criticize Starr Move, NEwSDAY, Jan. 26, 1999, at A20.

25. The House voted on October 8, 1998, to authorize an inquiry into impeachment. For a timeline of events, see Chronology of Clinton Inquiry, ASSOC. PRESS, Dec. 7, 1998, available in 1998 WL 23508957; see also THE IMPEACHMENT AND TRIAL OF PRESIDENT CLINTON, supra note 5.

As Michael Gerhardt has observed, the influence of federal prosecutors in triggering impeachment investigations of judges has been increasing in recent years. See Gerhardt, supra note 11, at 358-59. That trend too should be examined.

26. It is important to note that even though the independent counsel statute has expired, there may still be a question of what a special prosecutor should do with evidence that he believes suggests the occurrence of impeachable offense. See Bloch, Cleaning Up the Legal Debris, supra note 9, at 783-84. One possible model for future reports is Jaworski's report to the House. See Cleaning Up the Legal Debris, In re Report and Recommendation of June 5, 1972, Grand Jury Concerning Transmission of Evidence to the House of Representatives, 370 F. Supp. 1219 (D.D.C. 1974); see also KuTLER, supra note 15 , at $461-63$.

27. That is precisely where the House Judiciary Committee in the impeachment inquiry of President Richard Nixon began. That committee prepared a lengthy report on what constitutes an impeachable offense. See StAFf of THE House Comm. On the Judiciary, 93D Cong. 2D SESS., CONSTITUTIONAL GROUNDS FOR PRESIDENTIAL IMPEACHMENT (Comm. Print 1974). The committee then relied heavily on that report when it ultimately recommended that the full House impeach Nixon. See H.R. REP. No. 93-1305, at 6-8 (1974). 
though they had been warned by Starr that it contained salacious details. ${ }^{28}$ Even Ken Starr was surprised-and disappointed-by that precipitous action. ${ }^{29}$ Critical of the House's decision, former Representative Peter Rodino, Chairman of the House Judiciary Committee that voted to impeach Richard Nixon in 1974, observed, "The release ... caused positions to harden early along partisan lines before complex issues could be digested."

Finally, two months into the inquiry, a Subcommittee of the House Judiciary Committee agreed to explore the question of what constitutes an impeachable offense..$^{31}$ On November 9, 1998, in a marathon hearing, ${ }^{32}$ the Subcommittee on the Constitution heard from nineteen constitutional experts. ${ }^{33}$ The experts clearly disagreed on some things, but there was substantial agreement on several essential points. Most of us agreed that, to be impeachable, the actions of the President must seriously undermine the government and compromise his ability to continue governing. ${ }^{34}$ Moreover, most of us also agreed that even if the House thought the President's actions could be classified as "high crimes and misdemeanors," the House has the discretion not to impeach him. ${ }^{35}$ The

28. See H.R. REP. No. 105-830, at 124-26 (1998). "Starr [had] recommended that parts of the report and supporting documents be kept confidential, since they contain 'information of a personal nature." Mark Sherman, Starr Report Could Trigger Impeachment Proceedings, ATLANTA J. \& CONST., Sept. 10, 1998, at A1.

29. In an interview with Diane Sawyer, Starr said he was surprised to see the House release the report without reading it and regrets not doing more "to prevent the total and immediate public release of the details." 20/20: Ken Starr the Independent Counsel Speaks Out (ABC television broadcast, Nov. $25,1998)$. He was still upset about that decision a year later. Starr expressed regret that he had not tried harder to convince the House not to release the Starr Report: "To release it without examining the materials-Congress frequently receives very sensitive information-we sent the information up under circumstances that indicated that we viewed this as sensitive information." See CNN Inside Politics (CNN television broadcast Aug. 9, 1999).

30. Peter W. Rodino, Jr., The Vote that Changed America, N.Y. TimEs, July 27, 1999, at A19.

31. An earlier scheduled hearing had been postponed. An informal inquiry was held instead on October 15, 1998. See Schmitt, supra note 6, at A18 (quoting Professors Laurence Tribe and Susan Low Bloch).

32. The hearing ran from about 9:30 a.m. until nearly 8:00 p.m. See Background and History of Impeachment, supra note 8, at 1,319.

33. See Ruth Marcus, Judiciary Panel Signals It Will Pursue Impeachment: Legal Experts Testify on Constitutional Standards, WASH. POST, Nov. 10, 1998, at A1.

34. The words differed, but the scholars generally agreed that to be impeachable, a President's conduct had to injure the republic, the Constitution, or the government. See generally Background and History of Impeachment, supra note 8. As Professor Tribe observed,

All [those testifying] appear to agree that proof of ordinary crimes is neither necessary nor sufficient to undo the results of a national election in this way. The issue, as it emerged in the House Judiciary Committee hearings on November 9, came down to just how extraordinary and dangerous to the republic the Clinton crimes, if proven, would be.

Laurence H. Tribe, Rule of Law v. Rule of Life, Boston GlOBE, Nov. 16, 1998, at A15.

35. Gary L. McDowell remarked:

In the end, the determination of whether presidential misconduct rises to the level of "high Crimes and Misdemeanors"... is left to the discretion and deliberation of the House of Representative. No small part of that deliberation ... must address what effect the exercise of this extraordinary constitutional sanction would have on the health of the republic, as weighed against the necessity of making clear that in America no one is above the law.

Background and History of Impeachment, supra note 8, at 44; see also id. at 61 (statement of Matthew Holden); id. at 80 (statement of John C. Harrison); id. at 89 (statement of Cass R. Sunstein); id. at 94 
principal point on which we disagreed was whether his actions warranted impeachment. On this point, we were divided roughly in half. ${ }^{36}$

Unfortunately, neither the full Judiciary Committee nor the House as a whole ever articulated or agreed on a general standard. ${ }^{37}$ More significantly, the experts' consensus regarding the House's discretion was overlooked or disregarded. The Representatives truly misunderstood their role. The responsibility of the House in deciding whether to impeach is greater than a grand jury's decision whether to indict. The question should not simply be whether there is probable cause that the accused committed an impeachable offense; rather, a responsible representative should vote to impeach only if he or she believes that the accusations warrant removal from office. ${ }^{38}$ Representative Bill McCullom's suggestion that impeachment should be used to "brand" President Clinton with a "scarlet letter" is clearly wrong. Impeachment is an extreme remedy by which the legislature can remove an official who should no longer remain in office. It is not a punishment and

(statement of Richard D. Parker); id. at 161 (statement of John O. McGinnis); id. at 230 (statement of Laurence H. Tribe); id. at 231 (statement of Susan Low Bloch); id. at 241 (statement of William Van Alstyne); id. at 249-50 (statement of Jack N. Rakove); Gerhardt, supra note 11, at 373. See generally Marcus, supra note 33, at A1.

36. Seven scholars believed that President Clinton had committed impeachable offenses. See Background and History of Impeachment, supra note 8, at 30 (statement of Gary L. McDowell); id. at 108 (prepared statement of John O. McGinnis); id. at 118 (statement of Stephen B. Presser); id. at 184 (statement of Charles J. Cooper); id. at 195 (statement of Griffin B. Bell); id. at 237 (statement of William Van Alstyne); id. at 255 (prepared statement of Jonathan Turley). Eight scholars believed that the accusations either did not rise to the level of impeachable offenses or did not warrant impeachment. See id. at 68 (prepared statement of Matthew Holden); id. at 89 (prepared statement of Cass R. Sunstein); id. at 98 (statement of Arthur M. Schlesinger, Jr.); id. at 116 (prepared statement of Robert F. Drinan); id. at 206 (prepared statement of Daniel H. Pollitt); id. at 229 (prepared statement of Laurence H. Tribe); id. at 236 (prepared statement of Susan Low Bloch); id. at 246 (statement of Jack. N. Rakove). The opinions of the remaining scholars (Michael Gerhardt, John C. Harrison, Richard D. Parker, and Forrest McDonald) are more guarded. Even some scholars, such as Professor William Van Alstyne who believed that Clinton's conduct constituted impeachable offenses, said the House should not impeach. See id. at 238.

37. The fact that neither the House nor the Senate adopted a uniform definition of "high Crimes and Misdemeanors" should not be surprising. Neither has ever officially adopted such a uniform definition, but, as Michael Gerhardt notes, the results reached by the Senate over the centuries suggest an implicit agreement that one should be impeached and removed only for misconduct that poses "serious injury to the republic" and "has had a nexus between the official's misconduct and the official's formal duties." Gerhardt, supra note 11, at 375; Background and History of Impeachment, supra note 8, at 47-49, 55-56 (prepared statement of Professor Michael Gerhardt).

38. While Judge Posner says that "in an impeachment, the role of the House corresponds to that of a grand jury," RICHARD POSNER, AN AFFAIR OF STATE: THE INVESTIGATION, IMPEACHMENT, AND TRIAL OF PRESIDENT CLINTON 120 (1999), it is not clear that he would advocate a vote to impeach if the House member believed that removal from office was unwarranted. While he does not address that specific question, he does assert that a member of the House should vote to impeach only if he or she believes the evidence is there to convict, see id. at 121 , and that conviction by the Senate requires removal. See id. at 98 n.8. Further, he notes, that "because the trial of a President before the Senate is such a costly and disruptive process, it seems clear that the House ought to believe that the President is guilty, not merely that he may be, before it votes to impeach." Id. at 120.

39. "Members can fairly look at this with a reasonable expectation that the Senate will not convict and plausibly may not even try him. But if they believe the president should be branded and given the scarlet letter, the ultimate censure-impeachment-is the right way to do that." Ruth Marcus, Panel Unclear on Impeachment Role: Lawmakers Clash in Attempt to Define Standards and Constitutional Duties, WASH. POST, Dec. 6, 1998, at A8 (quoting Rep. Bill McCollum). 
should not be invoked lightly. ${ }^{40}$ The public had the right approach. As Professor Tribe observed, "[t]o treat what the [P]resident is alleged to have done as though it spells a national emergency requiring the second presidential impeachment in as many centuries seems ridiculous to the broad public beyond the Beltway .... On the wide screen that the public views, nothing could feel more disproportionate." ${ }^{41}$

The question of whether the House should have called witnesses or done any independent fact-finding is difficult to assess. Its decision not to do so and to rely entirely on the facts alleged in the Starr Report was, as Michael Gerhardt observed, "unusual" attacked as "partisan or unfair." ${ }^{43}$ At the same time, it must be noted that the

40. As Viscount Bryce described impeachment, it is "a hundred-ton gun which needs complex machinery to bring it into position, an enormous charge of powder to fire it, and a large mark to aim at." Such a weapon, he said, should not be used for light or transient causes, "as one does not use a steam hammer to crack nuts." I JAMES BRYCE, THE AMERICAN COMMONWEALTH, 1888, at 208-09 (1st ed., MacMillan \& Co., London \& New York 1889).

Even for those who think that grand jury indictment is the appropriate analogy, there was significant testimony questioning whether a typical prosecutor would seek an indictment from a grand jury for the wrongs President Clinton was alleged to have committed. In the House Judiciary Committee, a panel of distinguished prosecutors testified that a responsible federal prosecutor would not have brought a criminal prosecution on the basis of the case set out in the Starr Report. See Impeachment Inquiry, William Jefferson Clinton, President of the United States, Presentation on Behalf of the President: Hearing Before the House Comm. on the Judiciary, 105th Cong. 285 (1998) (statement of Thomas P. Sullivan) ("It is my opinion that the case set out in the Starr report would not be prosecuted as a criminal case by a responsible [f]ederal prosecutor."); id.at 295 (statement of Richard Davis) ("I do not believe that a case involving this kind of conflict between two witnesses would be brought by a prosecutor, since it would not be won at trial."); id. at 314 (statement of Edward S.G. Dennis, Jr.) ("The circumstances simply would not warrant the bringing of a criminal prosecution, and a criminal prosecution would most likely fail."); $i d$. at 318 (statement of Ronald Noble) ("I submit that a federal prosecutor ordinarily would not prosecute a case against a private citizen based on the facts set forth in the Starr referral."); id. at 329 (statement of William F. Weld) ("I agree with everyone who's spoken before about whether a perjury prosecution here really lies.").

At another hearing of the Judiciary Committee, Alan M. Dershowitz testified that "the false statements of which President Clinton is accused fall at the most marginal end of this least culpable genre of this continuum of offenses, and would never even be considered for prosecution in the routine cases involving an ordinary defendant." The Consequences of Perjury and Related Crimes: Hearing Before the House Comm. on the Judiciary, 105th Cong. 85 (1998); see also 145 CONG. REC. S1503 (1999) (statement of Sen. Sarbanes). As the Fifth Circuit noted in United States v. Cox, the decision to prosecute is in the discretionary power of the executive branch and "may well depend on matters of public policy wholly apart from any question of probable clause." 342 F.2d 167, 171 (5th Cir. 1965). Prosecutors should not prosecute if they believe conviction would be inappropriate. A decision to impeach, like a decision to indict, should not be used as method of branding and should not be used as a "scarlet letter."

41. Tribe, supra note 34, at A15.

42. In fact, the six months spent on the entire impeachment process, from the time of the referral until the Senate acquittal, was the third-shortest period ever spent on an impeachment. See Gerhardt, supra note 11, at 365 . The shortest was that of President Johnson, whose process lasted about three months, followed by Judge Claiborne, whose process lasted four months. See id.; ELEANORE BushNELl, CRIMES, FOLLIES AND MISFORTUNES 293-301 (1992)

43. Gerhardt, supra note 11, at 360. As Professor Gerhardt notes, the impeachment of President Johnson was the first time the House did not undertake independent fact-finding, but in that case, the House had conducted some limited fact-finding in an earlier, unsuccessful attempt to impeach, and was impeaching him this time for violating a law, a matter that needed little fact-finding. See id. at 359; JOHN R. LABOVITZ, PRESIDENTIAL IMPEACHMENT 49 (1978). The only other impeachment in which the House did not engage in its own fact-finding was the impeachment of Judge Harry Claiborne; there, 
Democrats were clearly urging the House to act quickly and to set a short timetable. $^{44}$

On the much-discussed question of censure, the House missed an important opportunity to responsibly debate and decide the constitutionality of such a measure. Representative William Delahunt of Massachusetts conducted an informal inquiry of the nineteen experts who had testified on November 9, 1998, and learned that a majority believed that a resolution of disapproval was clearly constitutional. ${ }^{45}$ As one of those queried by Representative Delahunt, I responded that the House (and the Senate) may assert its opinion on anything it wants, including its belief that the President engaged in inappropriate behavior. $^{46}$ While I believe members of Congress should exercise this power cautiously, there is nothing in the Constitution, including the prohibition against bills of attainder, that precludes such a resolution. ${ }^{47}$ As long as the censure resolution does not impose a fine or punishment, but merely states the opinion of the members of the legislative body, it is difficult to see how the bill of attainder clause is a bar. ${ }^{48}$ Indeed, the spirit of both the First Amendment ${ }^{49}$ and the Speech or Debate Clause ${ }^{50}$ suggests the value of such a resolution.

the House relied on the record compiled in a prior criminal conviction. See Gerhardt, supra note 11, at 360; MARY L. VOLCANSEK, JUDICIAL IMPEACHMENT 52 (1993).

44. See E.J. Dionne, Jr., Impeachment Problems for Everyone, WASH. PosT, Nov. 17, 1998, at A27 ("Hyde may think he's damned if he does and damned if he doesn't since it's the Democrats who urged him to move quickly.").

45. See Joan Biskupic, Many Scholars Say Censure is an Option: GOP Leaders Call It Unconstitutional, But Historical Evidence is Less Clear, WASH. POST, Dec. 15, 1998, at A19. The letters collected by Representative Delahunt are reprinted in IMPEACHMENT INQUIRY, supra note 7, at 578618. Of the 19 scholars surveyed, 12 responded that a censure or resolution of disapproval would be constitutional, so long as no punishment were imposed. See id. at 580-81 (letter of Griffin B. Bell); id. at 582-83 (letter of Susan Low Bloch); id. at 586-87 (letter of Michael J. Gerhardt); id. at 590-91 (letter of Matthew Holden, Jr.); id. at 592 (letter of Forrest McDonald); id. at 598 (letter of Richard D. Parker); id. at 600 (letter of Daniel H. Pollitt); id. at 604-05 (letter of Jack N. Rakove); id. at 606-07 (letter of Arthur Schlesinger, Jr.); id. at 608-09 (letter of Cass R. Sunstein); id. at 612-13 (letter of Laurence H. Tribe); id. at 618 (response of William Van Alstyne). Three scholars responded that censure would be unconstitutional. See id. at 594-95 (letter of Gary L. McDowell); id. at 596 (letter of John O. McGinnis); id. at 602 (letter of Stephen Presser). One scholar responded that censure was not unconstitutional, but rather "extra-constitutional and contrary to the process created by the Framers." See id. at 615 (letter of Jonathan Turley). Two scholars did not respond, see id. at 619, while the remaining scholar stated he did not have an opinion, see id. at 584 (letter of Charles J. Cooper). See also Editorial, Constitutional Room for Censure, WASH. POST, Nov. 11, 1988, at A26 (quoting Professors Tribe and Van Alstyne).

46. See IMPEACHMENT INQUIRY, supra note 7, at 582-83 (letter of Susan Low Bloch).

47. See id.; see also Joseph I. Lieberman, Editorial, The One Reasonable Solution, N.Y. TIMES, Nov. 29, 1998, § 4, at 9; Benjamin Wittes, Editorial, Congress Can Censure Anything, N.Y. TIMES, Dec. 2, 1998, at A29; Ruth Marcus, House Takes Up "Awful" Task with Time Short and Options Unclear, WASH. POST, Nov. 15, 1998, at A2 (explaining the arguments on both sides of the censure debate). But see Neil A. Lewis, Censure May Face Hurdle: The Constitution, N.Y. TIMES, Nov. 2, 1998, at A23; Dan Quayle, Editorial, Censure is Not an Option, N.Y. TIMES, Nov. 16, 1998, at A21; Eric Schmitt, Testing of a President: The Penalty, N.Y. TIMES, Dec. 13, 1998, § 1, at 1 ("A resolution or amendment proposing censure of the President in lieu of impeachment violates the rules of the House, threatens the separation of powers, and fails to meet constitutional muster." (quoting Rep. Henry Hyde)).

48. See Gerhardt, supra note 11, at 376-77. The Judiciary Committee Report also contains a discussion of bills of attainder and censure. See H.R. REP. NO. 105-830, at 135 (1998).

49. U.S. CONST. amend. I.

50. Id. art. I, $\S 6, \mathrm{cl} .1$. 
But the House did not openly debate and decide this issue. ${ }^{51} \quad$ Instead, it proceeded directly to vote on the four articles proposed by the Judiciary Committee, adopting two and rejecting two. Specifically, the House adopted the article that accused the President of lying to the grand jury in August 1998, and the article that accused him of obstructing justice in the Paula Jones case. ${ }^{52}$

51. See Biskupic, supra note 45, at A19. The Judiciary Committee had considered a joint resolution of censure, but rejected it by a vote of 14-22. H.R. REP. No. 105-830, at 135 (1998); see also Edward Walsh, The Bitterness of Being in the Minority: House Democrats Watch Helplessly as Republican Juggernaut Rolls On, WASH. POST, Dec. 19, 1998, at A27. The presiding officer ruled that an amendment to the impeachment resolution to substitute censure was out of bounds and that ruling was upheld by the full House by 230-204, with one member not voting. See 144 CONG. REC. H12,03839 (1998). Rep. Richard Gephardt noted in frustration:

In this debate, we are being denied a vote as an alternative to impeachment for censure and condemnation of our president for the wrongful acts that we believe have been performed. I know ... you say that the Constitution does not allow this vote for censure. Constitutional scholars in the hundreds ... have opined that ... the Constitution in no way prevents us from doing this.

Id. H11,777-78. Rep. David Bonior was even more outraged:

The American people have made it very clear they oppose impeachment. They are looking for another solution .... Censure ... is the one option the Republican leadership refuses to consider. They will not even let us vote on it .... Members on both sides of the aisle support censure. I dare say if it was made in order, it would pass. Yet the Republican leadership in this House is so angry, so obsessed, so self-righteous, that they are refusing us a true vote of conscience.

144 CONG. REC. H11,779 (1998). The House also refused to address the question of the legitimacy of impeachment by a lame-duck House. See Bruce ACKerman, THE CASE Against Lameduck IMPEACHMENT (1999); Posner, supra note 38, at 128-30.

52. The House rejected the proposed articles that accused the President of lying in the Paula Jones deposition and of refusing to respond accurately to the inquiries of the House of Representatives. Specifically, the House voted as follows: adopting proposed Articles I (228-206, 1 not voting) and III (221-212, 2 not voting), and rejecting proposed Articles II (205-229, 1 not voting) and IV (148-285, 2 not voting). See H.R. Res. 611, 105th Cong. (1998), 144 CONG. REC. H12,040-42 (1998).

The two articles adopted by the House became Articles I and II in the Senate. Article I alleged:

In his conduct while President of the United States, William Jefferson Clinton, in violation of his constitutional oath faithfully to execute the office of President of the United States and, to the best of his ability, preserve, protect, and defend the Constitution of the United States, and in violation of his constitutional duty to take care that the laws be faithfully executed, has willfully corrupted and manipulated the judicial process of the United States for his personal gain and exoneration, impeding the administration of justice, in that:

On August 17, 1998, William Jefferson Clinton swore to tell the truth, the whole truth, and nothing but the truth before a Federal grand jury of the United States. Contrary to that oath, William Jefferson Clinton willfully provided perjurious, false and misleading testimony to the grand jury concerning one or more of the following: (1) the nature and details of his relationship with a subordinate Government employee; (2) prior perjurious, false and misleading testimony he gave in a Federal civil rights action brought against him; (3) prior false and misleading statements he allowed his attorney to make to a Federal judge in that civil rights action; and (4) his corrupt efforts to influence the testimony of witnesses and to impede the discovery of evidence in that civil rights action.

In doing this, William Jefferson Clinton has undermined the integrity of his office, has brought disrepute on the Presidency, has betrayed his trust as President, and has acted in a manner subversive of the rule of law and justice, to the manifest injury of the people of the United States.

Wherefore, William Jefferson Clinton, by such conduct, warrants impeachment and trial, and removal from office and disqualification to hold and enjoy any office of honor, trust, or profit under the United States.

Article II alleged: 
These became Articles I and II that were sent to the Senate.

The majority's decision not to allow a discussion or vote on a resolution of censure ever-either before or after the vote on the articles-was unfortunate and probably led to the somewhat surprising letter written by four House Republicans to the Senate, in which they said, after voting to impeach, "We are not convinced, and do not want our votes interpreted to mean that we view removal from office as the only reasonable conclusion of this case." ${ }^{53}$ That letter suggested that their vote to impeach was irresponsible. If a member of the House does not believe that removal is warranted, he should vote against impeachment. Voting to impeach and send the case to the Senate, while hoping that the Senate will acquit, is inappropriate and irresponsible. ${ }^{54}$

IV

\section{THE SENATE}

The House vote sent the case to the Senate, where, fortunately, the senators acted more responsibly, although not flawlessly. Because it was only the second

In his conduct while President of the United States, William Jefferson Clinton, in violation of his constitutional oath faithfully to execute the office of President of the United States and, to the best of his ability, preserve, protect, and defend the Constitution of the United States, and in violation of his constitutional duty to take care that the laws be faithfully executed, has willfully corrupted and manipulated the judicial process of the United States for his personal gain and exoneration, impeding the administration of justice, in that:

(1) On December 23, 1997, William Jefferson Clinton, in sworn answers to written questions asked as part of a Federal civil rights action brought against him, willfully provided perjurious, false and misleading testimony in response to questions deemed relevant by a Federal judge concerning conduct and proposed conduct with subordinate employees.

(2) On January 17, 1998, William Jefferson Clinton swore under oath to tell the truth, the whole truth, and nothing but the truth in a deposition given as part of a Federal civil rights action brought against him. Contrary to that oath, William Jefferson Clinton willfully provided perjurious, false and misleading testimony in response to questions deemed relevant by a Federal judge concerning the nature and details of his relationship with a subordinate Government employee, his knowledge of that employee's involvement and participation in the civil rights action brought against him, and his corrupt efforts to influence the testimony of that employee.

See H.R. Res. 611, 105th Cong. (1998).

53. Letter on Shift to Censure, N.Y. Times, Dec. 21, 1998, at A28 (quoting letter of Reps. James C.

Greenwood, Michael Castle, Benjamin Gilman, \& Sherwood Boehlert to Senator Trent Lott).

While some have questioned whether the House has the constitutional authority to consider alternatives to impeachment, it seems clear to us that the Senate does have the authority and the precedents to consider a range of options. Those options should include a tough censure Id. proposal, which would impose a find and block any pardon.

54. As Elliott Richardson observed: "A vote to impeach is a vote to remove. If ... members believe that should be the outcome, they should vote to impeach. If they think that is an excessive sentence, they should not vote to impeach, because if they do ... the matter is out of their hands ...." The Consequences of Perjury and Related Crimes, supra note 40, at 149 . The minority reported:

The argument that the House is merely the body that accuses and the Senate is the body that tries, undermines the dual protection against misuse of the impeachment power that the founders intended. The Constitution requires more than that the House be a mere rubber stamp for sending allegations of wrongdoing to the Senate; rather Article II intends that the House as well as the Senate look at the same evidence with the same standards.

H.R. REP. NO. 105-830, at 211; see note 40, supra. 
time the Senate had tried a President, the first time it had tried an elected President, and the first trial of a President in which there were factual disputes, there were many unanswered procedural questions. The Senate answered some explicitly and others only implicitly. On balance, I would give the Senate a B+, or perhaps an A-, for their conscientious effort to conduct this process with the Constitution intact. ${ }^{55}$

One of the first questions the senators had to address was the meaning of the constitutional provision giving the Senate "the sole power to try all impeachments." 56 The Senate had previously adopted some general rules, but there were still many unanswered questions. Under the existing rules, the Senate must receive the House Managers' presentation of the articles, "proceed to the consideration of such articles," and "continue in session from day to day... after the trial shall commence... until final judgment shall be rendered." ${ }^{57}$ Thus, it was clear that the Senate could not ignore the House's articles of impeachment, and nothing suggests that the Senate ever seriously contemplated such action. However, the rules do not specify exactly how the Senate should "proceed to consider" the articles. Thus, the Senate had to decide whether it was required to have a full-blown trial, whether it could consider a motion to dismiss, and, if so, when it could do so. It also had to decide whether to adopt a uniform burden of proof or to continue the prior practice of allowing each senator to decide for himself or herself what the appropriate burden should be.

On January 9, 1999, the Senate unanimously adopted Senate Resolution 16, which outlined the specific procedures the Senate was to follow in the Clinton trial. $^{58}$ Under the resolution, a motion to dismiss could be brought, but only after the completion of several steps, namely the presentation of the articles by the House Managers, the response from the White House, and a sixteen-hour period of questioning by the senators. ${ }^{59}$ While the Senate's decision to delay the motion to dismiss until later in the proceedings was clearly appropriate, I believe that in the absence of such an agreement, a motion to dismiss could have been made at any time.

When a motion to dismiss was finally made on January 27, 1999, by Senator Byrd of West Virginia, it was defeated by a vote of fifty-six against and fortyfour for dismissal. ${ }^{60}$ Senate Resolution 16 had provided that a simple majority would control a motion to dismiss, ${ }^{61}$ and thus, had the motion been adopted by a

55. Needless to say, not everyone agrees with me. For example, Richard Posner referred to the process as "a travesty of legal justice." POSNER, supra note 38, at 127.

56. U.S. CONST. art. I, $\S 6, \mathrm{cl} .2$ (emphasis added).

57. S. Doc. No. 106-2, at 3 (1999).

58. S. Res. 16, 106th Cong. (1999).

59. See id. For an overview of the Senate proceedings, see Helen Dewar \& Peter Baker, Senate Debates Dismissal; Deliberation is Private Amid Search for Trial Endgame, WASH. Post, Jan. 26, 1999, at A1. A vote on the motion to dismiss would be in order only after debate on any motions to subpoena witnesses and present evidence not in the record. See S. Res. 16, 106th Cong. (1999).

60. See 145 CONG. REC. S1017-18 (1999).

61. See S. Res. 16, 106th Cong (1999). 
majority of the senators, the case would have been dismissed, and the President would have remained in office. What, if any, attention should the senators have paid to the fact that more than one-third of the senators voted to dismiss? One could argue that because the vote suggested there would not be the necessary two-thirds vote to convict, the case should have been dismissed even without majority approval. ${ }^{62}$ The Senate obviously did not do this. Presumably, the senators believed that with additional proceedings, some senators might change their minds, and that to dismiss the articles of impeachment before the process was complete would inappropriately allow one-third of the Senate to shortcircuit the actions of the other two-thirds. This decision will, and should, be precedent for future impeachments. ${ }^{63}$

Another question that arose was whether the Senate was required to allow the House Managers to call witnesses. Because the Senate chose to allow them to do so-although with significant limitations ${ }^{64}$-it is not known whether a decision not to have witnesses at all would also have been appropriate. As the Supreme Court suggested in Nixon v. United States, ${ }^{65}$ the Senate has enormous discretion in deciding how to proceed. However, the Senate (and the House) should be particularly conscientious in exercising its discretion. The decision

62. After the vote, Sen. Daschle stated, "The president will not be removed from office.... For the good of the country, and in keeping with the Constitution, it is now time to end this trial. It is time to move on." Peter Baker \& Helen Dewar, Senate Votes to Take Testimony; Nearly Party-line Decisions Foreshadow Eventual Clinton Acquittal, WASH. POST, Jan. 28, 1999, at A1 (quoting Sen. Daschle); see also Editorial, Closing Time, N.Y. TIMES, Jan. 26, 1999, at A22.

63. The Senate agreement provided that a simple majority would control any motion to dismiss as well as the witness plan. See Dewar \& Baker, supra note 59, at A1; Allison Mitchell \& Eric Schmitt, The President's Trial: The Overview; Witness Wrangling Goes on as Senate, in Closed Session, Debates a Dismissal Motion, N.Y. TIMES, Jan. 25, 1999, at A1. On January 25, 1999, the Senate voted 57-43 to reject an attempt to require public debate on the motion to dismiss the impeachment articles. See Senate Roll Call, WASH. POST, Jan. 26, 1999, at A12.

64. By a vote of 54-44 on January 28 , the Senate adopted, essentially along party lines, the Republicans' plan for witnesses - the videotaped deposition of Monica Lewinsky, Vernon Jordan, and Sidney Blumenthal. The depositions would occur on three consecutive days with one senator from each party present; the questioning would be done by two House Managers and two of the President's lawyers. Each deposition would last no more than 6 hours, with each side allocated 3 hours. After viewing the videotapes, the senators would decide if additional testimony was needed. See 145 CONG. REC. S1070 (1999); see also Dewar \& Baker, supra note 59, at A1; THE IMPEACHMENT AND TRIAL OF PRESIDENT CLINTON, supra note 6, at 367-68.

After the depositions were taken-Lewinsky on February 1, Jordan on February 2, and Blumenthal on February 3-the Senate reconvened on February 4 and voted as follows: to admit the transcripts and tapes into evidence (100-0); to reject a motion to have Monica Lewinsky testify in person (70-30); and to allow use of the videotapes in presentations before the Senate (62-38). See 145 CONG. REC. S1209-10 (1999).

65. 506 U.S. 224, 230 (1993).

The conclusion that the use of the word "try" in the first sentence of the Impeachment Trial Clause lacks sufficient precision to afford any judicially manageable standard of review of the Senate's action is fortified by the existence of three very specific requirements that the Constitution does impose on the Senate when trying impeachments: The Members must be under oath, a two-thirds vote is required to convict, and the Chief Justice presides when the President is tried. These limitations are quite precise, and their nature suggests that the Framers did not intend to impose additional limitations on the form of the Senate proceedings by the use of the word "try" in the first sentence.

Id. 
whether or not to call witnesses should depend on whether credibility is an issue, whether the House heard witnesses, and whether other factors suggest that a fair trial requires witnesses. The Senate's resolution of this issue in this case was, in my opinion, responsibly nuanced. ${ }^{66}$

One of the most contested questions was whether the Senate could have a bifurcated vote, asking first whether to convict the President, and second whether to remove him. Senator Susan Collins of Maine suggested such an approach, ${ }^{67}$ apparently influenced by an article by Professor Joseph Isenbergh at the University of Chicago. ${ }^{68}$ However, the suggestion was flawed. The Constitution provides that "the President, Vice President, and all civil Officers of the United States, shall be removed from Office on Impeachment for, and Conviction of, Treason, Bribery, or other high Crimes and Misdemeanors." ${ }^{{ }^{69}}$ The "shall" clearly suggests that removal is required if there is a conviction." Many of us, including Judge Robert Bork and Professor Laurence Tribe, believed that the suggestion to hold two votes was clearly unconstitutional, and so informed the Senate. ${ }^{71}$

66. See Ruth Marcus, Senate's Quandary: Does a Trial Have to Look Like "Perry Mason”? WASH Post, Jan. 7, 1999, at A12 ("As the Senate convenes the second presidential impeachment trial in history today, the question is what that trial should entail-whether it needs to look, as Georgetown University law professor Susan Low Bloch put it, like 'the Perry Mason version of a trial,' or whether something less would suffice.").

67. David Rosenbaum, The President's Trial: The Rules; Lott Picks Six Scouts to Hunt Exit, N.Y. TiMES, Jan. 27, 1999, at A19.

68. Joseph Isenbergh, Impeachment and Presidential Immunity from Judicial Process, 18 YALE L. \& POL'Y REV. 53, 86-91 (1999). Professor Isenbergh asserts that while the Constitution requires removal for conviction of high crimes and misdemeanors, it permits lesser punishment for conviction of lesser offenses. Under that interpretation, the Senate could vote to convict the President, but then vote to allow him to stay in office. An updated version of the article was recently published in 18 YALE LAW \& POLICY REviEw 53 (1999). Professor Douglas Kmiec of Pepperdine endorsed this view. See Douglas W. Kmiec, Editorial, Convict, But Don't Remove Clinton, WALL ST. J., Jan. 29, 1999, at A14.

69. U.S. CONST. art. II, $\S 4$ (emphasis added).

70. It is true that in the early impeachment trials of John Pickering in 1802, West Humphreys in 1862, and Robert Archbald in 1913, the Senate took two separate votes, first on guilt and second on removal. See Gerhardt, supra note 11, at 378-79. However, it is also true that in all three cases, the officials were convicted and removed from office. Starting with the trial of Judge Halsted Ritter in 1936, the President pro tempore ruled that removal is automatic following a guilty verdict, and no vote adopting a separate removal order was required. See 80 CONG. REC. 5607 (1936); see also 145 CONG. REC. S1489 (1999) (statement of Sen. Joseph R. Biden).

71. See, e.g., Rosenbaum supra note 67, at A19 (discussing Professor Tribe's objections). Professor Tribe objected to a bifurcated vote on conviction and removal. See id. In his words, "the Isenbergh approach is clearly unconstitutional." Id. However, Tribe went on to say that it would be "permissible for the Senate to vote to express its opinion that the President committed the offense with which he was charged, but to forego conviction on the ground that the offenses were not the high crimes necessary for removal." Id.

The natural reading of the words [of the impeachment clauses] ... is that the Senate may not attach additional penalties; removal and disqualification are all the Senate may decree... . The Isenbergh-Kmiec thesis gratuitously charges the Framers with sloppy draftsmanship. If there were anything to [this] theory, it should have been mentioned in the history of the founding. But one looks in vain in the Federalist Papers, Farrand's Records of the Convention, the ratifying debates, or anywhere else for support for their unique hypothesis .... [Professor Isenbergh's] new reading of the impeachment clauses would... produce thoroughly pernicious results.

Judge Robert Bork, Editorial, Read the Constitution: It's Removal or Nothing, WALL ST. J., Feb. 1, 
When enough senators became convinced that the Constitution, in fact, requires that conviction and removal be linked, several senators, including Collins, Snowe, Domenici, and Jeffords, proposed a variation: First vote on something they termed "findings of fact" and then vote on whether to convict and remove..$^{72}$ Again, many legal scholars objected, contending that this proposal was an improper end-run around the constitutional requirement of linkage. ${ }^{73}$ Under the Constitution, the Senate's sole function is "to try" the articles of impeachment and decide whether they warrant removal from office. The congressional remedy of impeachment should not replace the judicial process. The Constitution authorizes Congress to examine the official's behavior so as to decide whether he or she should remain in office. The question of criminal behavior and possible punishment are for the judiciary, not Congress. $^{74}$

Fortunately, the Senate ultimately agreed: There was only one vote and no findings of fact. ${ }^{75}$ Presumably, that approach will control future impeachments.

1999, at A21. For a more elaborate refutation of Isenbergh's suggestion, see Gerhardt, supra note 11, at $378-82$.

Senator Robert Byrd also believed that bifurcation was impermissible. See Frank Ahrens, Robert Byrd's Rules of Order: For the Senator, A Tough Job Demands a Strong Constitution, WASH. Post, Feb. 11, 1999, at C1 ("The Constitution is a cul-de-sac when it comes to impeachment. There is no escape exit. There is only one way and that is to deal directly with the articles of impeachment." (quoting Byrd)).

72. See Lorraine Adams, A Freshman With an Endgame Idea: An Unassuming Advocate, Collins Hopes "Findings of Fact," Will Send the Message, WASH. POST, Jan. 29, 1999, at A1.

73. See Eric Pianin \& Guy Gugliotta, Senate's Fiercest Partisan Battle Possible Over 'Findings of Fact', WASH. Post, Feb. 4, 1999, at A7. Judge Robert Bork also disapproved of this proposal. See Bork, supra note 71, at A21 ("Frustration and rage are poor guides to constitutional interpretation ... and these notions [bifurcated vote and 'findings of fact'] are preposterous readings of the Constitution as well as utterly impractical."); see also Bruce Ackerman, An Unconstitutional Republican Exit Strategy for Impeachment, L.A. TIMES, Feb. 3, 1999, at B7; Letter to Senator Harkin from Professors Vicki Jackson and Susan Bloch, Feb. 3, 1999 (on file with author); Eric Pianin \& Joan Biskupic, Senators Exploring A Form of Censure Are Bumping Into Obstacles, WASH. PosT, Jan. 28, 1999, at A17 ("Legal Experts say any proposal for separate votes on whether Clinton is actually guilty of particular charges and whether he should be removed from office likely would be forbidden."). Others, however, supported the proposed findings of fact. See, e.g., Charles Krauthammer, Editorial, The Case for $a$ Two-Part Judgment, WASH. POST, Feb. 2, 1999, at A15.

74. Cf. Article I, section 3 (providing that impeachment and conviction does not preclude criminal prosecution) and Article I, section 9 (prohibiting Congress from adopting a bill of attainder).

75. See Eric Schmitt, The President's Trial: The Proceedings, Senate Unity on Reprimand is Elusive, N.Y. TIMES, Feb. 5, 1999, at A23. According to Schmitt:

Republicans sought to approve a "findings of facts" that concluded that Mr. Clinton committed wrongdoing without removing him from office .... Republican sponsors said they would put the motion up for a vote only if at least five Democrats backed the plan. When none did today, saying it was unconstitutional, Republicans all but pulled the plug on the Id. proposal.

After the Senate voted not to convict and remove President Clinton, Senators Dianne Feinstein and Robert Bennett proposed a strongly worded censure resolution, which condemned President Clinton's behavior as "shameful, reckless, and indefensible." 145 CONG. REC. S1666 (1999). However, the vote on censure was procedurally blocked by Senator Phil Gramm, and the supporters of censure could not get the two-thirds vote required to permit the resolution to be considered, failing 43 to 56 . See id at S1462. Senator Feinstein placed the resolution in the record, signed by 29 Democrats and 9 Republicans. See id at S1666; Eric Schmitt, The President's Acquittal: The Rebuke; In the End, Senate 
The question each senator must answer when casting that solitary vote is multifaceted: Did the alleged behavior occur and does it constitute a "high crime and misdemeanor" warranting removal? The questions cannot be divided into separate votes; an official can be removed from office only if twothirds of the senators present answer both parts of the question affirmatively. ${ }^{76}$

\section{THE CHIEF JUSTICE}

Assessing the conduct of the Chief Justice, I would give him an $\mathrm{A}+$, but then his responsibility was fairly limited. Basically, his role was that of traffic cop, but he performed it well and with humor, something that clearly was needed and appreciated. ${ }^{77}$ The Supreme Court as a whole, however, could have spared us this whole saga had it decided that the Paula Jones suit needed to wait until President Clinton was out of office. The Supreme Court's decision was wrong, and thus, if I were grading the Court on that issue, I would give it a failing grade. $^{78}$

VI

\section{THE CONSTITUTION}

Finally, one must assess the Constitution itself. Here, the evaluation is more difficult, and experts' assessments vary widely. Some, like Professor Laurence Tribe, enthusiastically applauded the Constitution. Writing in the New York Times on the day of the Senate vote, Professor Tribe announced, "When it ends today with President Clinton's widely anticipated acquittal, the impeachment drama will have yielded few heroes-except the Constitution's Framers, whose

Passes No Harsh Judgment on Clinton, N.Y. TIMES, Feb. 13, 1999, at A8.

76. This is not to say that all the senators, in fact, asked this question. Their approaches to their votes varied. Each senator decided for himself or herself what the burden of proof should be. Three standards were mentioned: preponderance of the evidence, clear and convincing evidence, and beyond a reasonable doubt. Most of the senators chose between the latter two. Some, including Senators Dodd and Bryan, adopted the reasonable doubt standard because the articles of impeachment in this case were based on criminal statutes. See 145 Cong. Rec. at S1594, S1609 (1999). Some, including Senator Mikulski, adopted this standard because removing a President is such a serious step. See id. at S1498. Others, such as Senators Kohl, Jeffords, Leiberman, and DeWine, believed that only clear and convincing evidence was required because impeachment is not a criminal proceeding. See id. at S1547, S1594, S1601-03, S1622-24. For a good description of the various approaches adopted by the senators, see Gerhardt, supra note 11, at 355-58. Judge Posner agrees that senators are to make their own determination of whether the alleged wrongdoing constitutes a "high crime or misdemeanor," notwithstanding the fact that a majority of the House thought it did. See POSNER, supra note 38, at 121.

77. Demonstrating his dry wit, Chief Justice Rehnquist quipped during his closing remarks to an amused Senate, "I underwent the sort of culture shock that naturally occurs when one moves from the very structured environment of the Supreme Court to what I shall call, for want of a better phrase, the more free-form environment of the Senate." Joan Biskupic, For Rehnquist, A Trying Experience; Despite Lampooning, Chief Justice Will Return with Dignity in Place, Court Watchers Say, WASH. Post, Feb. 13, 1999, at A33 (quoting Chief Justice Rehnquist); see also Joan Biskupic, In a Court He Doesn't Rule, Chief Justice Now Finds His Role; Presiding Over the Senate Is a Different Kind of Trial for Nation's Highest Judge, WASH. PosT, Jan. 23, 1999, at A13.

78. See Bloch, supra note 3, at A20. 
wisdom that drama will again have vindicated."79 The New York Times editorial page agreed: Its headline proclaimed, "The System Worked." Kathleen Sullivan, Dean of Stanford Law School, were more critical of the Constitution and applauded instead the good sense of the public. ${ }^{81}$ Professor Ronald Dworkin believes that it is too early to judge whether the Constitution worked. A strong opponent of the effort to impeach Clinton, Dworkin wrote:

The long, disgraceful story revealed a dangerous threat to the separation of powers that is the Constitution's structural heart. If the politicians who control Congress are numerous enough, and partisan or zealous or angry enough, they can remove a democratically elected president they dislike simply by finding some misdeed that they can label a "high crime." ... Impeachment [should be] a last resort . . . used only in an emergency when it would be evidently dangerous to the Constitution and the nation to allow the president to continue in office.... The Republicans in the House put the nation through months of hearings, debate, and trial, weakening the presidency, preoccupying Congress, and monopolizing public attention, on grounds that did not remotely [constitute an impeachable offense]. ${ }^{82}$

At the other extreme, there were those like Professor John McGinnis of Fordham University who said that the impeachment process was a valuable, cathartic experience that ought to be more readily available and more often employed. ${ }^{83}$

My assessment lies somewhere in the middle of these extremes. The constitutional design worked reasonably well. To the extent I was unhappy with the process, I would attribute the fault more to the mistakes of the individual actors, than to the procedures prescribed by the Constitution. On the one hand, the President was not convicted and remains in office. If you believe, as I do, that acquittal was the correct result, then the Constitution gets high marks for requiring a supermajority in the Senate. On the other hand, if you believe, as I also do, that the House should not have ever impeached him, then maybe we should make impeachment more difficult. Perhaps we should amend the Constitution to require a supermajority in the House as well as in

79. Laurence H. Tribe, Editorial, And the Winner Is . . , N.Y. TIMES, Feb. 12, 1999, at A27.

80. Editorial, The System Worked, N.Y. TIMES, Feb. 13, 1999, at A18.

81. Kathleen M. Sullivan, Madison Got It Backward, N.Y. TIMES, Feb. 16, 1999, at A19. Dean Sullivan remarked:

In contrast, it was the people's representatives who displayed what Madison, in Federalist No. 10, called "factious tempers." The House majority and most Republicans in the Senate insisted that the President had betrayed the public confidence so as to warrant removal, no matter how much the public insisted he had not. Pay no attention to those opinion polls, said impeachment advocates; the matter should turn not on the will of the many but on the Id. conscience of the few.

82. Ronald Dworkin, The Wounded Constitution, N.Y. REV. BooKs, Mar. 18, 1999, at 8. It is tempting to say ... that the public responded as it did out of constitutional wisdom or deep respect for the office of the presidency-that it understood the constitutional principles at stake better than the politicians did. But a combination of other factors seems at least an equally good explanation of why the public gave the President such support. The economy is Id. unprecedentedly strong, Starr was unattractive and clumsy, and the House managers inept.

83. See John O. McGinnis, Impeachable Defenses, POL'Y REV., June-July 1999, at 27. 


\section{the Senate. ${ }^{84}$}

Having graded the various institutions, the overall grade point average for the impeachment process is somewhere around a "C-" or "D." we turn to the second question: What have we learned about our constitutional system from this wrenching and torturous experience, and how can we improve things should we face the unfortunate event of the impeachment of another President?

\section{VII}

\section{LESSONS FOR THE FUTURE}

Before the House's vote on impeachment, there was much talk that voting to impeach President Clinton for his alleged behavior would "lower the bar."

84. Not everyone agrees that impeachments should be rare. Professor John O. McGinnis has argued that the impeachment of President Clinton fulfilled the Machiavellian suggestion that such conflicts are useful to cleanse the system: "Thus, in the aftermath of impeachment, we should not be thinking about how to avoid such contests in the future, but about how to build more of them into our system." Id. That, however, seems to be a minority view. Most scholars believe that impeachment is a drastic remedy that should be difficult to invoke and rarely used. See, e.g., Dworkin, supra note 82; Sullivan, supra note 81, at A2; Tribe, supra note 79, at A27.

85. While this report card evaluates only the governmental institutions involved in the Clinton impeachment, others have critiqued non-governmental institutions such as the media and academia. For evaluations of the media, see BILl KOVACH \& TOM ROSENSTIEL, WARP SPEED: AMERICA IN THE AgE OF MiXed MediA (1999); see POSNER, supra note 38, at 240-46; Gerhardt, supra note 11, at 36063, 388-89; Tom Hamburger, Impeach the Media?, STAR TRIB., Feb. 15, 1999, at 13A; Howard Kurtz, Kathleen Wiley: Old News; Questions Remain, But the Press Loses Interest, WASH. POST, May 17, 1999, at C2; Matt Zoller Seitz, Media Coverage Burned the Scandal at Both Ends, Public Disgusted by Events, NeW ORleans Times-PiCAYune, Feb. 14, 1999, at 14A.

For criticism of academia, see POSNER, supra note 38, at 240-42; Neal Devins, Bearing False Witness: The Clinton Impeachment and the Future of Academic Freedom, 148 U. PA. L. REV. 165 (1999); Gehardt, supra note 11, at 354, 389. The criticism is multifaceted. To the extent academics are criticized for being uninformed or lacking expertise, the criticism, if accurate, is well-taken. See POSNER, supra note 38, at 240-46; Devins, supra at 170-71; Gerhardt, supra note 11, at 389. But I question the accuracy of the criticism. To assert, as Devins does, that because a prominent constitutional law casebook devotes only one page to the issue of impeachment, "it is doubtful that professors of constitutional law ... were well positioned to render an expert opinion on the subject," is both inaccurate and absurd. Devins, supra, at 170-71. It is inaccurate because the casebook to which Devins refers, in fact, devotes more than one page to impeachment, specifically pages $80,130-32$, and because I personally can attest to the fact that I have taught about impeachment for all of the 18 years I have taught constitutional law. It is absurd because one cannot measure expertise by the number of pages in one casebook.

To the extent the criticism is that members of the academy should only "report ... actual events" and should not analyze them and predict or "speculate" possible consequences of various alternatives, the criticism confuses the roles of reporters and commentators. See Gerhardt, supra note 11, at 389. It is perfectly appropriate, indeed desirable, for academics to use their expertise to predict possible outcomes. Finally, the fact that many academics believed that impeaching President Clinton for his misconduct was an inappropriate and undesirable use of the impeachment power does not mean those commentators were acting with an undisclosed "political, personal, or partisan agenda," or were "abusing academic freedom." Devins, supra, at 166. They, like a large majority of the public, simply believed that impeachment was the wrong way of dealing with President Clinton's misbehavior and said so. The fact that Clinton and his supporters were pleased with that response is understandable but does not mean the commentators were "acting at the request of the President." Gerhardt, supra note 11, at 389. For an excellent response to the Devins critique, see Cass Sunstein, Professors and Politics, 148 U. PA. L. REV. 191 (1999). 
Did it? Did the House's decision to impeach lower the bar for future impeachments? Or did the ultimate acquittal by the Senate mean that it will be more difficult to impeach in the future? What about the assertions of people, like me, who argued that impeachment is like a nuclear weapon that should be unleashed only for the most grievous wrongs, and who predicted that impeachment would distract and undermine the ability of the President to continue functioning? ${ }^{86}$ Obviously, President Clinton continued to perform his duties and the government was not totally derailed by the impeachment process, although I do believe that the process did distract and weaken President Clinton and virtually all of the other institutions it touched. ${ }^{87}$ Will President Clinton's extraordinary ability to "compartmentalize" to continue functioning make future impeachments more likely? Will this impeachment make future Presidents more subservient to Congress? The answers depend on whether the future emphasizes the actions of the House or those of the Senate.

The House impeached too easily, and if this impeachment is the model for the future, the bar has certainly been lowered. Whether President Clinton's conduct constituted a high crime and misdemeanor, warranting his removal from office, was, at best, a close question. The House should have exercised its discretion and decided not to impeach. Even Professor William Van Alstyne, one of the highly esteemed professors invited by the Republicans to testify, suggested that the President's actions did not warrant impeachment. ${ }^{89}$

86. See Ronald Dworkin, A Kind of Coup, N.Y. REV. BooKs, Jan. 14, 1999, at 61. "The power to impeach a president is a constitutional nuclear weapon and it should be used only in the gravest emergencies." Id.; see also Background and History of Impeachment, supra note 8, at 63 (statement of Susan Low Bloch) ("Impeachment of the President is a grave event. It undoes a national election, removes the embodiment of one of the three branches of government, and therefore should be reserved for only the most serious misdeeds."); Laurence Tribe, in id. at 22 ("Removing a President, even just impeaching him, paralyzes the country .... [Impeachment] may be a caged lion, but it will lose its fangs if we use it too promiscuously and would permanently weaken the President and the Nation, leaving a legacy all of us in time would come to regret deeply."). Arthur Schlesinger, Jr., observed:

Lowering the bar to impeachment creates a novel, indeed revolutionary theory of impeachment, a theory that would send us on an adventure with ominous implications for the Separation of Powers that the Constitution established as the basis of our political order. Let us recall the impeachment of President Andrew Johnson .... . He was rescued in 1868, but even the failed impeachment had serious consequences for the presidency. The aftermath bound and confined the President for the rest of the century.

Id. at 99 .

87. Peter Rodino recently observed, "The Clinton impeachment has cost us dearly, allowing both foreign problems and domestic issues to languish." Rodino, supra note 30, at A23.

88. William Safire, "Compartmentalization Chic" Reigns, Hous. CHRON., Feb. 21, 1999, at Outlook 6. Professor Dworkin observed, "Clinton's dogged persistence and charm surpassed expectations yet again. We were saved from a constitutional disaster, not by the Framers' prescience, but by Clinton's political skills, and by his and our sheer good luck." Dworkin, supra note 82, at 8 .

89. In his inimitable style, Professor Van Alstyne stated,

[I]f the President did that which the special counsel report has declared, they are crimes of such a low order that it would unduly flatter the President by submitting him to trial in the Senate.... The [alleged] behavior in the aggregate has now struck me in retrospect as low crimes indeed. That is to say, behavior which in retrospect is pusillanimous and reprehensible and hardly worth the time of this Nation to forward to the Senate for trial for the outcome 
But it is also possible that the lesson to be learned from this saga will be more informed by the Senate's acquittal. The Senate decisively rejected the two articles of impeachment adopted by the House. Not only did the articles not receive the two-thirds vote required by the Constitution, neither article even earned a majority of senatorial support. ${ }^{90}$ Thus, it is possible that posterity will decide that the House was wrong to impeach and that, therefore, impeachment will be more difficult in the future, at least for behavior comparable to that of President Clinton. ${ }^{91}$

What did we learn about the meaning of "high crimes and misdemeanors" and whether it has the same meaning for judges and for Presidents? ${ }^{92}$ Many in both the House and Senate assumed that the standard for impeaching judges and the President should be identical. Members frequently repeated the syllogism: Judges have been impeached and removed for perjury; Presidents should not be held to a lower standard; therefore, Presidents should be impeached and removed for perjury. ${ }^{93}$ The question is whether that syllogism is

would be very doubtful.

Background and History of Impeachment, supra note 8, at 281, 238.

90. Article I, which alleged perjury before the grand jury, failed by a vote of 45 guilty, 55 not guilty. Article II, which alleged obstruction of justice in the Paula Jones case, failed by a vote of 50 guilty, 50 not guilty. See 145 CONG. REC. S1458-59 (1999). Judge Posner believes this result was backwards. In his view, the evidence supporting Article I was stronger than that supporting Article II. See PosNER, supra note 38, at 58 .

91. To some extent, the answer will be influenced by the election results of November 2000, although as always, the results, whatever they may be, are likely to be ambiguous. Professor Gerhardt believes that the office of the presidency was strengthened by this process and that future impeachments of Presidents for behavior such as President Clinton's are unlikely. See Gerhardt, supra note 11 , at $365,385-88$.

92. As noted previously, neither the House nor the Senate adopted a single definition of "high crimes and misdemeanor." See supra note 35 . But in the expert testimony before the House Judiciary Committee, there was a general consensus that to be impeachable, a President's conduct had to injure the republic, the Constitution, or the government. See supra note 34. As Michael Gerhardt has observed, the Senate by its actions over the last two centuries seems to have agreed that the disputed action must cause serious harm to the republic and have a nexus between the official's misconduct and the official's formal duties. See Gerhardt, supra note 11, at 375.

93. Comments by Representatives Hutchinson and Canady were typical: "This House has impeached and the Senate has removed from office federal judges for lying under oath. Now it is contended that these impeachments aren't relevant,... that somehow we should set a lower standard for the President of the United States than the standard that has already been set by [Congress] for a federal judge. I simply disagree with that." IMPEACHMENT INQUIRY, supra note 7, at 328-29 (statement of Rep. Canady). Mr. Hutchinson stated, "So it is your view that [a judge may be impeached for false statements] but that is not an acceptable standard for the President of the United States? ... And therefore we are basically setting a higher standard for the judges of our land than we are the President of the United States and the chief law enforcement officer." Id. at 177.

Similar sentiments were expressed in the Senate: "No one is above the law. I cannot accept the argument that a different standard applies to judges than to the President." 145 CONG. REC. S1616 (1999) (statement of Sen. Thurmond). "It is telling that on three separate occasions, the Senate has removed federal judges from office for perjury. Judges are tried under the same Constitutional provision... as are presidents.... Clearly, under Senate precedent, perjury is a "high crime and misdemeanor." Id. at S1618 (statement of Sen. Crapo).

Three times in the last fifteen years, the House has impeached and the Senate has removed a federal judge for perjury or related crimes.... The Senate's precedents on perjury as an impeachable offense are clear. Moreover, there is simply no basis in the Constitution to apply a less demanding standard to the President than has been traditionally applied to federal 
correct.

The Constitution provides that " $[\mathrm{t}]$ he President, Vice President, and all civil Officers of the United States, shall be removed from Office on Impeachment for, and Conviction of Treason, Bribery, or other high Crimes and Misdemeanors." It seems reasonably clear that it does, and past practice over the last two centuries supports this. ${ }^{95}$ In fact, the initial belief was that civil officers also included legislative officials, but ever since the failed attempt to impeach and remove Senator Blount in 1799, it has been understood that legislators are not subject to impeachment. ${ }^{96}$

Even though judges are civil officers subject to impeachment, there is the interesting question of what is the impact of the "good behaviour" clause in Article III of the Constitution. Does the statement that judges serve "during good behaviour" mean only that they have life tenure, with no bearing on the impeachment clause, or does it add another ground for the impeachment and removal of a judge? ${ }^{97}$ Congress touched on this question during the recent impeachment debates, but gave us mainly rhetoric and little analysis. For the sake of the future, we should provide more guidance.

While the question is not trivial, the legislative history of the Constitution suggests that the "good behaviour provision" is essentially addressed to the question of the tenure of judges and does not add a substantive provision to the impeachment clause. Most scholars agree that judges are impeachable only for

judges.

Id. at S1615 (statement of Sen. Ashcroft); see also id. at S1500 (statement of Sen. Grams); id. at S1528

(statement of Sen. Frist).

94. U.S. CONST. art. II, § 4.

95. The idea that judges are civil officers for the purpose of impeachment was announced contemporaneously with the ratification of the Constitution:

The precautions for [federal judges'] responsibility are comprised in the article respecting impeachments. They are liable to be impeached for mal-conduct by the house of representatives, and tried by the senate, and if convicted, [they] may be dismissed from office and disqualified from holding any other. This is the only provision on the point which is consistent with the necessary independence of the judicial character, and is the only one which we find in our constitution in respect to our own judges.

The Federalist No. 79, at 532-33 (Alexander Hamilton) (J. Cooke ed., 1961). This view has been reinforced by historical precedent. Of the 17 federal impeachments, 13 have been of federal judges (the other 4 were 2 Presidents, 1 senator, and 1 cabinet officer.) See Background and History of Impeachment, supra note 8, at 357-72.

96. In 1797, the House impeached Senator Blount for his alleged involvement in a plot with England to invade Spanish Florida and Louisiana. Relying on several different constitutional passages, Blount's attorney was successful in convincing the senators that members of Congress are not civil officers. Article II, section 2 gives the president the power to appoint ambassadors, judges, and other officers; Article I, section 5 gives each House the power to expel its own members; Article I, section 6 forbids the appointment of senators or representatives to any civil office during their congressional tenure. On January 7, 1799, the Senate voted 14-11 to dismiss the case for lack of jurisdiction. This vote has been accepted as precedent that senators and representatives are not impeachable. See BUSHNELL, supra note 42, at 25-41. Each House can, however, expel one of its members. See U.S. CONST. art. I, § 5.

97. U.S. CONST. art. III, $\S 1$ provides, in pertinent part: "The judges, both of the supreme and inferior Courts, shall hold their Offices during good Behaviour." 
"treason, bribery, or other high crimes and misdemeanors" and that bad behavior is not an additional criterion. ${ }^{98}$

Even if the good behaviour clause does not modify the definition of an impeachable offense, the fact that judges have life tenure should inform the exercise of the discretion the House and Senate possess. In particular, when the House or Senate is debating whether particular misconduct warrants impeachment and removal, a legislator ought to consider not only the alleged misconduct, but also the nature of the official's duties, and whether he or she has limited or life tenure. The Framers deliberately placed the power to impeach and remove in the legislative branch; it is a political remedy by which the people's representatives can remove a public official who can no longer properly serve the people. In other words, legislators have discretion and should consider many factors when deciding whether to impeach and remove an official. Specifically, they should consider the duties of the official, the length of service remaining, and the disruption to the country that removal would cause. It should not be surprising, therefore, for a member of Congress to conclude that, even for essentially similar conduct, it is perhaps more necessary to remove a life-tenured judge than to remove a term-limited President. ${ }^{99}$ This is particularly true if, as has too often been the case, the judge has been convicted of a crime and is sitting in jail while still on the federal payroll. ${ }^{100}$

98. For an excellent discussion of the debate and this conclusion, see MICHAEL GERHARDT, THE FEDERAL IMPEACHMENT PROCESS: A CONSTITUTIONAL AND HISTORICAL ANALYSIS 82-86 (1996).

There is a separate, equally interesting, question of whether the "good behaviour" phrase allows the judiciary to discipline, or even remove, one of its own. See RAOUL BERGER, IMPEACHMENT: THE CONSTITUTIONAL PROBlems 127-88 (1974); GERHARDT, supra at 82-102; Harry T. Edwards, Regulating Judicial Misconduct and Divining "Good Behavior" for Federal Judges, 87 MICH. L. REV. 765 (1989); Robert Kramer \& Jerome Barron, The Constitutionality of Removal and Mandatory Retirement Procedures for the Federal Judiciary: The Meaning of "During Good Behavior," 35 GEO. WASH. L. REV. 455 (1967); Burke Shartel, Federal Judges-Appointment, Supervision, Removal-Some Possibilities Under the Constitution, 28 MICH. L. REV. 870 (1930).

99. Several members of the House and Senate understood the distinction. See, e.g., 145 CoNG. REC. S1503 (1999) (statement of Sen. Sarbanes); id. at S1510 (statement of Sen. Robb); id. at S1525 (prepared statement of Sen. Cleland); id. at S1567 (statement of Sen. Kennedy); id. at S1488 (prepared statement of Sen. Biden).

Many scholars agree with this. See, e.g., Background and History of Impeachment, supra note 8, at 88-89 (prepared statement of Cass Sunstein); id. at 194 (prepared statement of Charles Cooper); id. at 221 (statement of Laurence Tribe); id. at 232 (statement of Susan Low Bloch); Akhil Amar, Trial and Tribulation, New RePubliC, Jan. 18, 1999, at 17-20. Judge Posner agrees, but placed more emphasis on the facts that (1) because judges are appointed and not elected, impeachment of a judge is less likely to be attributed to political motives and (2) because judges symbolize law, even minor crimes gravely undermine the system of legal justice. See Posner, supra note 38, at 103-04. By contrast, says Posner, Presidents, as politicians, "are expected to obey the law, but not to personify it." Id. at 104.

However, contending that the same behavior by judges may not warrant impeachment if committed by a President is not to say that judges should "be removed for misbehavior that falls short of an impeachable offense." Gerhardt, supra note 11, at 372-73. It is simply saying that conduct which may constitute an impeachable offense for a judge may not constitute an impeachable offense when committed by the president. I agree with Professor Gerhardt that the Clinton impeachment proceedings did not definitively answer this question, but instead "clouded" it. Id. at 353.

100. Both Judges Harry Claiborne and Walter Nixon were convicted and sent to jail, but remained as federal judges, drawing their salaries as before. The only way they could be removed from the federal bench and the federal payroll was to have Congress impeach and remove them. See VOLCANSEK, supra note 43, at 48,141. Judge Robert Collins was convicted and imprisoned for bribery 


\section{VIII}

\section{CONCLUSION}

Obviously, it is too early to judge the ultimate impact of this impeachment, but some predictions are possible. Hopefully, future Presidents will behave more appropriately and avoid this type of crisis. Fortunately, the independent counsel statute has expired and is not likely to be reenacted again, at least not in the near future. Maybe members of the House of Representatives will understand better the nature of their responsibilities with respect to impeachment. Procedural rules for impeachment, drafted prospectively instead of in the heat of battle, would be desirable. Clearly, the importance of a bipartisan approach to impeachment was underscored, although, of course, that cannot be legislated. ${ }^{101}$ In addition, the entire impeachment process reinforced the presumption that most scholars accept-that the only role the judiciary has in the impeachment of a President is the role played by the Chief Justice as presiding officer. Judicial review is likely to be limited at best. ${ }^{102}$ Finally, the

in 1993; he continued to receive his salary in jail until he resigned, after being threatened with impeachment. See Gerhardt, supra note 11, at 358 n.35. By contrast, it is generally believed that a President cannot be indicted and jailed while in office. See SEnATE HEARING (Sept. 9, 1998); Statement of Susan Low Bloch in IMPEACHMENT OR INDICTMENT: Is A SITTING PRESIDENT SUBJECT TO THE COMPULSORY CRIMINAL PROCESS? (S. Hrg. 105-969).

101. Representative Henry Hyde, Chairman of the House Judiciary Committee, clearly had it right when he observed early in the process: "An impeachment proceeding must be bipartisan in the final analysis .... It can't be seen as a purely political, vindictive, partisan exercise." Lloyd Grove, Clinton's Public Enemy: Even Before Monica Lewinsky, Bob Barr Had Impeachment on his Mind, WASH. Post, Feb. 10, 1999, at E1. Admittedly, it takes two parties to make an event bipartisan. So, in theory, one can accuse the Democrats of supporting the President, thus failing to make this impeachment bipartisan. However, the Nixon impeachment was notably different from that of Clinton. As Peter Rodino recently observed in discussing his handling of the Nixon impeachment,

[p]artisanship can never be eliminated from the impeachment process, but it can be minimized. In the Nixon case, the House Democratic leadership maintained a hands-off approach, allowing the Judiciary Committee to pursue an independent inquiry . . . . John Doar, the majority counsel, and the staff were instructed to make no inference or partisan statements. Because of our concern with confidentiality, we conducted much of our inquiry in executive session .... In the Clinton case, in contrast, both Mr. Starr and the majority counsel, David Schippers, were unabashed prosecutors of the President.

Rodino, supra note 30, at A23. Leonard Garment, counsel to President Nixon during Watergate offers a more critical retrospective on the Nixon impeachment:

[I]mpeachment is a highly political process. From our limited experience, it appears that whether an impeachment succeeds or fails in its aims depends on whether the partisanship can discipline itself well enough to make its case persuasive to the country as a whole. What public life needs is that type of discipline, and the moderation it brings, rather than an unachievable and even pernicious ideal of nonpartisanship.

See Editorial, Watergate, Without the Piety, N.Y. Times, Aug. 9, 1999, at A19.

102. As the Supreme Court indicated when Judge Walter Nixon contested the procedures used in his impeachment, most of the questions raised in the context of an impeachment and trial, at least in the impeachment of a judge, are political questions to be decided by the Congress and not the judiciary. See Nixon v. United States, 506 U.S. 224 (1992).

Certainly judicial review of the Senate's trial would introduce the same... bias as would participation in the trial itself. Second, judicial review would be inconsistent with the Framers' insistence that our system be one of checks and balances. In our constitutional system, impeachment was designed to be the only check against the Judicial Branch by the Legislature. 
investigation and impeachment of President Clinton raised many important questions that Congress should revisit, including questions of attorney-client privilege, executive privilege, protective function privilege, and temporary immunity for a sitting president. These questions will recur, whether or not there is another impeachment. Now that some of the impeachment passion has subsided, Congress should examine them in a non-partisan, dispassionate fashion. ${ }^{103}$

Chief Judge Posner accurately described the competing visions invoked by the Clinton-Lewinsky-Starr drama:

Even after unsubstantiated conjectures (such as Starr's being obsessed with sex, or Clinton's having tried to get Lewinsky a job so that she wouldn't tell the truth in the Paula Jones case) are put to one side, there are two diametrically opposed narratives to choose between. In one, a reckless, lawless, immoral President commits a series of crimes in order to conceal a tawdry and shameful affair, crimes compounded by a campaign of public lying and slanders. A prosecutor could easily draw up a thirtycount indictment against the President. In the other narrative, the confluence of a stupid law (the independent counsel law), a marginal lawsuit begotten and nursed by political partisanship, a naive and imprudent decision by the Supreme Court in that suit, and the irresistible human impulse to conceal one's sexual improprieties, allows a trivial sexual escapade ... to balloon into a grotesque and gratuitous constitutional drama. The problem is that both narratives are correct.

The critical question, however, is not which narrative one finds more accurate, but whether either narrative warranted putting the country through the turmoil, expense (in time and money), and international embarrassment this impeachment entailed. As this report card suggests, my answer is "no."

Id. at 234-35.

103. For some suggestions, see generally Bloch, Cleaning Up the Legal Debris, supra note 9.

104. POSNER, supra note 38, at 91-92. 